\title{
Self-Reported Mobile Phone Use \& Workplace Productivity between Age Groups
}

\author{
Jyotsna M Kalavar ${ }^{1 *}$ and Joshua Swinehart ${ }^{2}$ \\ ${ }^{1}$ Human Development \& Family Studies, Penn State University, USA \\ ${ }^{2}$ Penn State University, USA
}

*Corresponding author: Jyotsna M Kalavar, Penn State University, New Kensington campus, 3550 Seventh Street Road, New Kensington, PA 15068, USA

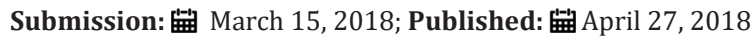

\begin{abstract}
This study explored the relationship between self-reported mobile phone for personal use during working hours and employee productivity in the workplace by different age groups. Eighty-five people participated in an online survey at a regional campus of a major university. A small percentage of participants (12\%) indicated that they had jobs that required the use of a smartphone. Duration and frequency of mobile phone use was examined in the context of respondent's age and self-perceived employee productivity. While smartphone use has the potential to improve workplace productivity, significant time is expended during working hours for personal use of such devices.
\end{abstract}

Keywords: Mobile phone use; Workplace productivity; Age differences in technology use; Age groups; Smartphone personal use; Social media

\section{Introduction}

Since two decades ago when the personal digital assistant was introduced, cellular devices have been widely popular in the work setting [1]. In the past decade or so, mobile phone use has become ubiquitous in people's everyday life [2]. Though initially seen as a luxury item that was affordable for a select few, the mobile phone is no longer cast in that mold. The use of these devices was further accelerated by the introduction of smartphones such as BlackBerrys and iPhones [3]. In 2014, Washington, Okoro \& Cardon [4] estimated that roughly $85 \%$ of American adults own a mobile phone.

The Pew Research center (2017) report suggests that Americans are now increasingly connected to the world of digital information while "on the go" via smartphones and other mobile devices. According to them, $95 \%$ of Americans now own a cellphone of some kind. There appears to be variability in smart phone ownership based on age, income, and educational attainment. For instance, $92 \%$ of those in the 18-29 age group had a cell phone compared to $74 \%$ in the 50-64 age group. Similarly, education and income were positively correlated with smart phone ownership numbers.

Smart phones are mobile phones that are beyond basic feature phones in that they offer advanced computing capabilities, including varied social networking possibilities. Social media affords the opportunity to engage in real-time conversations with others on Facebook, Twitter, etc. In 2014, Kaur affirmed that Facebook and Twitter were one of the most commonly used forms of communication for Generation Z (those born in the mid-1990s).
However, Kingston [5] found that applications such as Snapchat appeal to Generation $\mathrm{Z}$ than earlier generations. One thing is clear that newer social media applications tend to initially circulate with the younger generation [5] that is connecting faster and in distinct ways than previous generations [6].

The social media usage landscape is continually changing. Easily accessible now by smart phones, social media is increasingly being adopted by people of all ages. Young adults have been the earliest social media adopters and they continue to use these sites at higher levels but usage by older adults has increased in recent years. The Pew Research Center [7] estimates that nearly $80 \%$ of internet users use Facebook. While young adults continue to report using Facebook at high rates, the increase in numbers is primarily due to the entry of older adults into this medium. They estimated that $62 \%$ of online adults ages 65 and older now use Facebook, representing a 14 point increase from 2015. By contrast, Instagram rates are high among younger adults (18-29 years age group), nearly seven times the share among those 65 years in age. According to the Pew Research Center [8,9], social media is part of the daily routine for many users of all ages. They estimated that roughly three-quarters of Facebook users and about half of Instagram users visit these sites at least once a day.

In human communication, the mobile phone may be considered a breakthrough advance. What mobile phones today offer in terms of capabilities has extended far beyond their initial purpose of facilitating contact beyond two individuals. Today, mobile phones have games, video and camera capabilities, radio, music player, 
hard drive, and capabilities of streaming multimedia [10]. This means you can listen to music, play games, do your online banking, make travel arrangements, shopping, and track what others are doing just by tapping on the mobile phone. While such versatility in usage is a major advantage that allows for seamless integration of work, leisure, social communication, it also is a constant distraction that may interfere with what one is doing. With so many choices available on a handheld device, individuals may have difficulty with self-regulation and managing their choices strategically $[11,12]$.

Smart phones offer both opportunities and challenges. The ability to connect instantaneously and live with use of images and videos, exchange text and chat messages, internet capabilities that allow us to stay informed of happenings throughout the world is a technological marvel. Bertschek \& Niebel [13] found in their analysis that mobile internet use does cause higher labor productivity. But, this hyper-connected world entails constant bombardment of mental stimuli that one must keep pace with. In a study that employed biometrics and embedded cameras during non-working time, Marci [14] found that task switching occurred 27 times per hour among digital natives and 17 times per hour among those who grew up with older technologies. Lee [3] found that information overload increased negative emotions, and that the perceived usefulness of cell devices mitigated this effect. Such information overload, both work-related and personal, can take place on many and changing platforms all at once. There are clearly issues that surface regarding etiquette, addictive mobile phone use, social annoyance, awareness of one's surroundings, and how this may impact one's output. Cell phone technology is increasingly blurring the distinction between work and nonwork domains [15] It is not surprising then that in the workplace, organizations can allow this to become an "attractive nuisance" [16].

Multitasking involves some loss of quality or time. We are diverting our attention from one task to another or medium to another that can detract from either accuracy or speed [17]. Research suggests that smart phones are detrimental to cognitive performance. According to Gill \& Kamath [18], their use increases reaction time, reduces focus, and lowers performance of tasks that entail concentration and decision-making. It has been suggested that blocking off a certain time of the day to look at emails, review text messages may be the best way of focusing attention [16]. Otherwise, poor decision making outcomes may become a reality [19]. However, workplace demands may not necessarily facilitate this. Plus, there is the added distraction of social media for personal use in the workplace.

Social media websites are a large part of today's society as people post and tweet constantly about their life, use it as a forum to vent their concerns, and to connect with others in distant locations. Social media is now an integrated part of our lives as we see it on the smart phone, tablet, laptop, and even on television. Does social media influence our professional activities? There is a growing consensus that organizations must have distinct and specific social media policies to optimize workplace productivity during working hours. Organizational concerns regarding time and attention that employees expended on social media while on the job were reported by Cain [20]. This was particularly emphasized in the context of social media use via smartphone than via a computer as the smartphone provided portability levels that were constantly distracting. Research by Smith \& Darling [21] indicated that 55.6\% of 439 perfusionists admitted to using a cell phone, and nearly half $(49.2 \%)$ admitted they sent text messages while performing a cardiopulmonary bypass. About $7.3 \%$ of the perfusionists admitted that their cell phone had a negative impact on their work performance; there were also admissions of accessing email, surfing the Internet, and using social networking sites.

Most of the research literature on mobile phone use has focused exclusively on young adults, primarily in university settings [22]. That is not surprising since this group represents the first generation to have grown up with mobile phones. Their comfort level with mobile phone usage, preference for cell phone use over a landline phone, and expectancy of constant contact within their social network are somewhat unique to this group. According to Duggan \& Rainie [23], the percent of mobile phone ownership is said to be $94 \%$ among $18-29$ year olds and $90 \%$ for the age group 30-49 years old. Not only do mobile phone ownership rates vary among different age groups, but there are reportedly differences in text message and call minute usage between adults of varying ages. As reported by Becton \& Walker [24], organizations are being urged to recruit, reward, and manage their employees differently based on generational differences in attitudes, values, and desires. According to them, some have suggested that failure to identify these differences may lead to unsatisfactory organizational outcomes such as conflict, poor working relationships, and fewer organizational citizenship behaviours.

Texting is a method that is often relied upon to stay in touch with family and friends in a manner that respects the privacy and autonomy of the recipient. According to Forgays \& Hyman [25], texting as well as call minute usage was less among older age groups compared to those in the 18-24 age range. According to research by Hernandez Encuentra \& Pousada [26] older adults were most likely to use the mobile phone for the function of speaking rather than additional functions such as surfing the internet, taking photographs, and creating videos. Kurniwan [27] pointed out that older adults view mobile phones as a modern version of the landline. Washington \& Okoro [28] found dramatic age differences in informal meetings. Younger employees (21-30 years of age) considered checking text messages and emails, answering calls, and even writing text messages and emails as appropriate. This was in sharp contrast with employees 41 years of age and older who considered these actions inappropriate. These are important considerations in a multigenerational workplace environment where people of different age groups work together towards a common work goal.

In the workplace, information sharing, decision-making, coordination, influence and motivation are seen as some of the function of communication. As the average age of the American workforce has increased, a lot of attention has been directed to the 
fact that the workforce is largely comprised of three generations. Researchers like Atchley and Warden (2012) have pointed out that young adults may display signs of addiction to their cell phone as they feel the need to constantly check and respond to text messages. There may be some blurring of boundaries between personal and work domains in the workplace as the allure of round the clock connectivity with others is embedded in smart phones. This constant bombardment of information stimuli can lead to a drop in workplace productivity that can lead to serious performance review consequences. However, not all research supports this line of thinking. For instance, some researchers found that employers viewed smartphones as a way to increase worker productivity. Kalkbrenner \& McCampbell (2011) indicated through their research that "the vast majority of smartphone owners find that their productivity has increased versus those that own standard phones."

There is limited scientific literature available regarding selfreported use of mobile phones and social media and their possible impact on workplace productivity among different age groups. In an academic setting, the opportunity to assess individuals of various age groups, especially of the young adult age group is high since they are most likely to embrace newer forms of communication technology. Therefore, this study will focus on an examination of self-reported phone use and work productivity among different age groups in a small campus academic community. Our objective is to examine if different age groups differ in mobile phone usage in the workplace, and to understand possible implications for worker productivity.

\section{Method}

\section{Sample}

Of the 85 participants, the average age was 32.53 years $(S D=15.16)$. Forty percent of participants were male. Majority $(62 \%)$ were working students while $14 \%$ were faculty and $24 \%$ were staff members. Average reported working hours by students per day was 4.5 hours ( $S D=2.01$ ). Faculty and staff indicated an average of 8 hours per day on the job. On average, all the respondents indicated working for 6.01 hours per day $(\mathrm{SD}=3.04)$. Nearly all participants reported they owned a mobile phone (97\%). Of those that owned mobile phones, majority (89\%) indicated they were smartphone owners. Those with smartphones confirmed that besides phone calls, they have internet access, various apps, text and social media capabilities. A small percentage of participants (12\%) indicated that they had jobs that required the use of a smartphone.

\section{Procedure}

In this cross-sectional study at a southwestern PA university's branch campus, eighty-six students, faculty and staff members participated in an online survey. Through contact with the student government on campus, and listserv emails sent to the entire academic community, participation in this online survey was solicited. The online survey opened up around the mid-semester break of the spring semester on campus. This was done to maximize the likelihood of campus community participation during a relative lull period in the academic calendar. There were no financial or academic incentives provided for participation in this online survey. The survey remained open for approximately three weeks before the termination of data collection. This study was approved by the Institutional Review Board (IRB) of University.

\section{Measures}

Besides socio-demographic questions, the following questions were asked pertaining to the features that the mobile phone owners had on their device. The duration and frequency of reported cell phone use among respondents was assessed by the following questions:

A. On a scale from zero to ten with zero being the least productive and ten being the most productive, how would you best describe how your phone impacts your productivity during working hours?

B. During working hours in a normal day, how many minutes do you typically engage in the following activities for personal (non-business related) use:

a. Talk on the phone (incoming and outgoing)

b. Text (sending and receiving)

c. Use social media (FaceBook, Twitter, Instagram, etc.)

d. Use the internet (watching YouTube videos, checking e-mails, etc.)

e. Use apps

f. Play games

C. During working hours in a normal day, how many times do you typically engage in the following activities for personal (non-business related) use:

a. Place outgoing phone calls (respond to number of calls)

b. Receive incoming calls (respond to number of calls)

c. Send text messages (respond to number of text messages you send)

d. Receive text messages (respond to number of text messages you receive)

e. Check social media updates (respond about the number of times you check for updates)

f. Use the internet (watching YouTube videos, checking e-mails, etc.; respond on how many times you use the internet

g. Use apps (respond how many times you use apps)

h. Play games (respond how many times you play games)

D. During working hours, is your phone set to "off", "on", "silent" or "vibrate"?

E. How would you best describe your experience with using your phone while working? 


\section{Result}

Of those who owned smartphones, nearly all of them used their phone for purposes of a phone call, text messages, use of various apps, and internet use. Only $64 \%$ of them said they used it for games, and $75 \%$ indicated they used it for social media purposes. The sample was divided into three age groups: 18-25 years, 2649 years and 50 plus years. When asked how their smartphone impacted work productivity (on a scale from 0 to 10 with zero being least productive), the mean score reported was 4.76 (SD=3.01). The youngest age group of 18-25 year olds reported a mean score of 4.17 ( $S D=2.74$ ), the next age group of 26-49 year olds reported a mean score of 5.33 ( $\mathrm{SD}=3.22$ ), and the oldest age group of those 50 + years reported a mean score of $5.36(\mathrm{SD}=3.17)$. A one-way ANOVA yielded no significant age differences between age groups with regard to the self-reported impact on work productivity by cell phone use at work. The next self-reported assessment was about the frequency (number of times) phone use occurs during working hours. Results show participants reported using their phone for personal use, on average, 25 times on a typical working day ( $S D=11.56)$.

A chi-square test of independence was performed to examine the relationship between frequency of phone use during working hours by age groups (see Table 1). The relationship between these variables was significant in three of six areas: $\mathrm{X} 2(3, \mathrm{~N}=85)=11.74$, $\mathrm{p}<.05$ showed that the youngest age group was more likely to text than the other two age groups. Similarly, the youngest age group was more likely to play games than the other two age groups, X2 $(3, \mathrm{~N}=85)=13.56, \mathrm{p}<.05$, and was more likely to use social media than the other two older age groups during working hours, X2(3, $\mathrm{N}=85)=12.19, \mathrm{p}<.05$.

Table 1: Frequency of self-reported personal phone use (number of times) during working hours by age groups.

\begin{tabular}{|c|c|c|c|}
\hline Type of Use & $\mathbf{1 8 - 2 5}$ Years & $\mathbf{2 6 - 4 9}$ Years & $\mathbf{5 0 +}$ Years \\
\hline $\begin{array}{c}\text { Talking on the } \\
\text { phone }\end{array}$ & 24 & 20 & 15 \\
\hline Texting & $33^{*}$ & 21 & 15 \\
\hline Social media & $18^{*}$ & 12 & 4 \\
\hline Using internet & 24 & 22 & 19 \\
\hline $\begin{array}{c}\text { Using various } \\
\text { applications }\end{array}$ & 15 & 12 & 9 \\
\hline Playing games & $35^{*}$ & 22 & 14 \\
\hline \multicolumn{4}{|c|}{$* \mathrm{p}<.05$} \\
\hline
\end{tabular}

Participants responded that they expended an average of 33 minutes of their working time on personal cell phone use during working hours $(S D=22.64)$. Table 2 lists the number of selfreported minutes expended on the phone during working hours by the three age groups. A one-way ANOVA yielded a significant difference between the three age groups only with regard to texting. There was a statistically significant difference between groups as determined by one-way ANOVA $F(2,83)=6.30, p=.003)$. A Tukey post-hoc test revealed that the number of self-reported minutes expended on texting was statistically significantly lower for the $50+$ age group (1.47 $\pm 1.72 \mathrm{~min}, \mathrm{p}=.057)$ and youngest age group
(20.94 $\pm 25.83 \mathrm{~min}, \mathrm{p}=.005)$ compared to the middle age group $(7.25 \pm 7.83 \mathrm{~min})$. There were no statistically significant differences between the middle and oldest age groups ( $\mathrm{p}=.682)$.

Table 2: Number of minutes expended on phone use by age groups.

\begin{tabular}{|c|c|c|c|c|}
\hline \multirow{2}{*}{ Type of Use } & $\begin{array}{c}\mathbf{1 8 - 2 5} \\
\text { Years }\end{array}$ & $\begin{array}{c}\mathbf{2 6 - 4 9} \\
\text { Years }\end{array}$ & $\mathbf{5 0 + \text { Years }}$ & Total \\
\hline \multirow{2}{*}{$\begin{array}{c}\text { Talk on the } \\
\text { phone }\end{array}$} & 3.89 & 5.06 & 4.47 & 3.87 \\
\cline { 2 - 5 }$*$ Texting & $(\mathrm{SD}=11.35)$ & $(\mathrm{SD}=5.03)$ & $(\mathrm{SD}=4.37)$ & $(\mathrm{SD}=8.87)$ \\
\cline { 2 - 5 } & 20.94 & 7.25 & 1.47 & 13.08 \\
\hline \multirow{2}{*}{$\begin{array}{c}\text { Using social } \\
\text { media }\end{array}$} & $12.25 .82)$ & $(\mathrm{SD}=7.83)$ & $(\mathrm{SD}=1.72)$ & $(\mathrm{SD}=20.78)$ \\
\cline { 2 - 5 } & $(\mathrm{SD}=31.89)$ & $(\mathrm{SD}=12.59)$ & $(\mathrm{SD}=1.51)$ & $(\mathrm{SD}=24.05)$ \\
\hline \multirow{2}{*}{$\begin{array}{c}\text { Using } \\
\text { internet }\end{array}$} & 5.03 & 5.5 & 2.14 & 3.46 \\
\cline { 2 - 5 } & $(\mathrm{SD}=11.11)$ & -8.83 & $(\mathrm{SD}=4.18)$ & $(\mathrm{SD}=9.01)$ \\
\hline $\begin{array}{c}\text { Using } \\
\text { various } \\
\text { applications }\end{array}$ & 2.72 & 6.37 & 0.29 & 3.23 \\
\cline { 2 - 5 } & $(\mathrm{SD}=6.98)$ & $(\mathrm{SD}=16.63)$ & $(\mathrm{SD}=1.09)$ & $(\mathrm{SD}=10.16)$ \\
\hline \multirow{2}{*}{$\begin{array}{c}\text { Playing } \\
\text { games }\end{array}$} & 0.94 & 2.11 & 0.35 & 0.37 \\
\cline { 2 - 5 } & $(\mathrm{SD}=2.24)$ & $(\mathrm{SD}=6.30)$ & $(\mathrm{SD}=.06)$ & $(\mathrm{SD}=.44)$ \\
\hline \multicolumn{5}{|c}{${ }^{*} \mathrm{p}<.05$} \\
\hline
\end{tabular}

In this survey, the correlation between age and self- reported cell phone use in duration was shown to be significant $r(83)=-.278$, $\mathrm{p}<.05$. Similarly, frequency of cell phone use and age was shown to be significant $r(83)=-.391, p<.01$. The negative correlations imply that as the age of respondents increases, self-reported cell phone use (duration and frequency) decreases [28].

When asked about the phone setting during working hours, there were four choices provided: turned on, turned off, placed on silent mode, and placed on vibrate mode. See Figure 1 for description of responses by age groups. Less than $5 \%$ of the oldest age group turned their phones off during working hours. Nearly one-third of the youngest age group had their phone on vibrate mode during working hours.

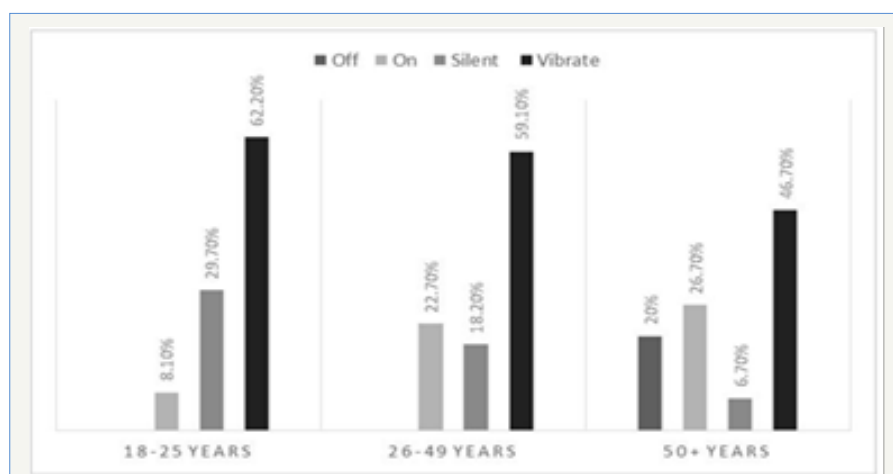

Figure 1: Self-report by employees of phone setting during working hours by age groups.

Participant responses to the question, "How would you best describe your experience with using your phone while working?" generated a multitude of responses. Sample responses from the youngest group spoke mostly of the distraction factor. Example: "I try to put it away so that I can focus on the material," "It usually 
distracts me to the point that I need to put it away or turn it off until my work is completed." The middle group comprising those in the 26-49 age group were more likely to acknowledge the usefulness but also point to the limitations. Example: "Phones are a doubleedged sword. They are the quickest way to look something up yet also the largest possible distraction that is constantly available," "Doesn't really affect me. I know when to look for things I need, and when to stop." However, the 50+ age group admitted limited usage of the phone's versatile features, and the primary reliance on it for texts and calls. Example: "I only use it to check the time or see if I missed a txt every half hour or so," "If someone calls or texts, I will answer otherwise I don't use my phone. I keep it aside when I am working."

\section{Discussion}

Mobile phone use for personal reasons during working hours has become ubiquitous among people of all ages. Though such usage has been acknowledged in this study, it is possible that the frequency and duration of cell phone use for personal reasons during working hours is grossly underreported by employees. Social desirability may play a role in driving the responses. While such phone use may improve workplace productivity when used for work purposes, employers must recognize the amount of company time that younger employees spend engaged in using these phones for personal use, and the distractive power inherent in them. The differences in cell phone use between younger and older adults may be contributed to the former group embracing technology more readily as well as being much more tech savvy than older age groups [29].

The use of smartphones in the workplace should be examined in terms of the tradeoff that exists between improved workplace productivity and the loss of company time. The implications of this study are instructive for employers who require, or are considering requiring their employees to have a smartphone for their job. How does the usage of smart phones vary within a cohort of employees? Are there regional or cultural implications of such usage considering this study was exclusively in southwestern Pennsylvania? Further, it behoves human resource personnel to strategize with regard to company policies on the general use of cell phones for personal use during working hours. Though differences between employees of varying ages may prevail with regard to use and productive workplace behaviors, organizations may be best served by the inclusion of flexibility in their policies and practices that targets the values and priorities of every age group (Table 3 ).

Table 3: Bivariate Correlations between Age, Duration, Frequency $\&$ Productivity.

\begin{tabular}{|c|c|c|c|c|}
\hline & Age & Duration & Frequency & $\begin{array}{c}\text { Level of } \\
\text { Productivity }\end{array}$ \\
\hline Age & ---- & $-.278^{*}$ & $-.391^{* *}$ & 0.154 \\
\hline Duration & & ---- & 0.156 & 0.009 \\
\hline Frequency & & & --- & -0.035 \\
\hline Level of & & & & -- \\
\hline productivity & & & & \\
\hline
\end{tabular}

A proactive approach of making employees more savvy with their phone use to meet work and personal demands may be to actively institute training sessions within the workplace. Specific policies formulating phone settings in the work place may offer explicit guideposts for acceptable employee work behaviors. The heavy reliance on digital communication by the youngest age group in the workforce may impact workplace communication. In future, organizations must determine the role of smartphone technology to enhance workplace relationships onsite but also be aware of possible resulting miscommunication as an outcome. This will shape the workplace culture to a large extent, and build stronger stronger intergenerational working relationships.

The cross-sectional nature of this study makes it impossible to explicitly test for age changes and life stage effects. Therefore, a longitudinal study is recommended that may allow for a better understanding of age changes, taking life stage and employment status factors into account. While these findings help us understand age group differences in mobile phone use within an educational context, we believe that future research on cell phone use and workplace productivity would benefit from surveys being conducted in varied work settings where participants will be of a wider age range and comprise a larger sample size.

\section{References}

1. Duxbury L, Higgins C, Smart R, Stevenson M (2014) Mobile technology and boundary permeability. British Journal of Management 25(3): 570588.

2. Castells M, Fernandez Ardevol M, Qiu JL, Sey A (2007) Mobile communication and society: A global perspective. MIT Press, Cambridge, USA.

3. Lee J (2016) Does stress from cell phone use increase negative emotions at work? Social Behavior and Personality 44(5): 705-716.

4. Washington MC, Okoro EA, Cardon PW (2014) Perceptions of civility for mobile phone use in formal and informal meetings. Business and Professional Communication Quarterly 77(1): 52-64.

5. Kingston A (2014) Get ready for generation Z Maclean's.

6. Kick A (2015) How Generation Z's reliance on digital communication can affect future workplace relationships. CF 13(2): 214-222.

7. Pew Research Center (2016) Social Media Update 2016.

8. Pew Research Center (2017) Social Media Factsheet.

9. Pew Research Center (2017) Mobile Fact Sheet.

10. Ali A, Papakie M, McDevitt T (2012) Dealing with distractions of cell phone misuse/use in the classroom - a case example. Competition Forum 10(20): 220-230.

11. Atchley P, Warden AC (2012) The need of young adults to text now: Using delay discounting to assess informational choice. Journal of Applied Research in Memory and Cognition 1(4): 229-234.

12. David P, Kim J, Brickman J, Ran W, Curtis C (2015) Mobile phone distraction while studying. New Media and Society 17(10): 1661-1679.

13. Bertschek I, Niebel T (2016) Mobile and more productive? Firmlevel evidence on the productivity effects of mobile internet use. Telecommunications Policy 40(9): 888-898.

14. Marci C (2012) A (biometric) day in the life: engaging across media. Paper presented at Re: Think 2012, New York, USA. 
15. Ragsdale J, Hoover C (2016) Cell phone during nonwork time: A source of job demands and resources. Computers in Human Behavior 57: 54-60.

16. Dance JW, Service RW (2013) The attractive nuisance: A model to prevent workplace distractions. Journal of Multidisciplinary Research 5(2): 35-51.

17. Gopnik A (2012) What's wrong with the teenage mind? The Wall Street Journal. pp. 28-29.

18. Gill PS, Kamath A, Gill TS (2012) Distraction: An assesment of smartphone usage in health care work settings. Risk Manag Healthc Policy 5: 105-114.

19. Davis G (2002) Anytime/anyplace computing and the future of knowledge work. Communications of the Association of Computing Machinery 45(12): 67-73.

20. Cain J (2011) Social media in health care: the case for organizational policy and employee education. Am J Health Syst Pharm 68(11): 10361040 .

21. Smith T, Darling E, Searles B (2011) 2010 Survey on cell phone use while performing cardiopulmonary bypass. Perfusion 26(5): 375-380.

22. Harley D, Winn S, Pemberton S, Wilcox P (2007) Using texting to support students' transition to university. Innovations in Education and Teaching International 44(3): 229-241.
23. Duggan M, Rainie L (2012) Cell phone activities 2012. Pew Researcher Center's Internet \& American Life Project. Washington DC, USA.

24. Becton J, Walker H, Jones Farmer A (2014) Generational differences in workplace behavior. Journal of Applied Social Psychology 44(3): 175189.

25. Forgays DK, Hyman I, Schreiber J (2014) Texting everywhere for everything. Gender and age differences in cell phone etiquette and use. Computers in Human Behavior 31: 314-321.

26. Hernandez Encuentra E, Pousada M, Gomez Zuniga B (2009) ICT and older people: Beyond usability. Educational Gerontology 35(3): 226245 .

27. Kurniwan S (2008) Older people and mobile phones: a multi-method investigation. International Journal of Human-Computer Studies 66: 889-901.

28. Hall SS (2011) Wisdom: From Philosophy to Neuroscience. Vintage, New York, USA.

29. Kaur P (2014) Relationship between social networking sites usage pattern and motivations behind usage: a study of generation Z 'a digital generation.' International Journal of Applied Services Marketing Perspectives 3(2): 996-1004.
Creative Commons Attribution 4.0

International License

For possible submissions Click Here

\section{Submit Article}

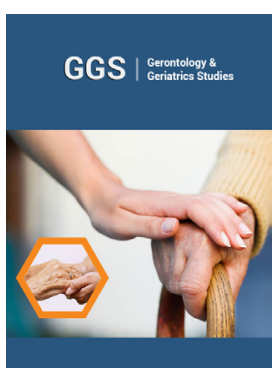

\section{Gerontology \& Geriatrics Studies}

\section{Benefits of Publishing with us}

- High-level peer review and editorial services

- Freely accessible online immediately upon publication

- Authors retain the copyright to their work

- Licensing it under a Creative Commons license

- Visibility through different online platforms 